\title{
16-17. SZÁZADI FALUSI PÉNZHAMISÍTÁS RÉGÉSZETI NYOMAI TOLNA MEGYÉBEN
}

\author{
Varga Máté ${ }^{1}-$ K. Németh ANDrás ${ }^{2}$ \\ Magyar Régészet 10. évf. (2021), 1. szám, pp. 62-69. https://doi.org/10.36245/mr.2021.1.6
}

„,Sötét erdők rejtekén, pór kunyhókban homályos származású, elzülött emberek silány érczböl egy-egy süveg monétát vagy lengyel garast gyártottak" (KомÁRомY 1893a, 648). Komáromy András mintha az alább közölt irásunkban bemutatandó Tolna megyei lelöhelyeket jellemezte volna 1893-ban a Századok címü folyóirat lapjain megjelent írásában. Az általa leirt kép a mohácsi csatavesztés utáni zavaros időket mutatja be, amikor szegény emberek is megpróbálkoztak a pénzhamisitás tiltott tevékenységével. A nemesek pénzhamisitási törekvéseit pedig egy, ezzel a tevékenységgel vádolt férfi (Miklós mester) vallomásán keresztül ismerhetjük meg Komáromy munkájából.

A numizmatika tudományának egyik legérdekesebb fejezete a pénzhamisitás, hiszen - kis túlzással amióta vertek pénzeket, azóta hamisitották is öket. A téma különlegessége ellenére a mai napig még mindig viszonylag keveset tudunk róla. Különösen hiányos a tudásunk az úgynevezett falusi pénzhamisitó mühelyekröl, amelyekröl - a föúri pénzhamisitással szemben - az írott forrásaink is hallgatnak. Tanulmányunkban ehhez a témakörhöz szeretnénk hasznos régészeti adatokkal hozzájárulni a hódoltság korára és egy viszonylag kis, de annál intenzivebben érintett területre vonatkozóan, elsösorban fémkeresös kutatások és terepbejárások segitségével.

Kulcsszavak: pénzhamisítás, numizmatika, kora újkor, török kor, Tolna megye, Dél-Dunántúl

\section{TÖRTÉNETI ÁTTEKINTÉS}

A pénzhamisítás már az Árpád-kortól kezdve jelen volt a Magyar Királyságban, bár írott források nem igazán tesznek róla említést. Törvényekben sem térnek ki külön rá, így minden bizonnyal a szokásjog alapján számított már akkor is hütlenségnek, illetve felségsértésnek (KAHLER 1977-1978, 57-59). A pénzhamisítás kisebb-nagyobb mértékben minden században felütötte a fejét, de igazán nagy méreteket elöször Luxemburgi Zsigmond (1387-1437) uralkodása alatt öltött, amikor már nemcsak egyéni, kis mértékben elkövetett hamisításról van tudomásunk, hanem a büncselekményt elkövetök egy-egy földesúr védelme alatt dolgoztak. Ismert jelenség volt a pénzverdékben történt hamisítás is; vagy esetleg a verdéből megszerzett verőtövet használták fel máshol jogtalanul (KAHLER 1981-1982, 79-80). Az 1526-os mohácsi csata után a két új király - I. Ferdinánd (1526-1564) és Szapolyai János (1526-1540) - törvényes pénzverése mellett az ország több föura és nemese is veretett jogtalanul pénzt, ami az országgyüléseken is rendszeresen napirendi téma volt. Ezt a korszakot a fơúri pénzhamisítás időszakának nevezi a kutatás. Ebből az időszakból régészeti szempontból az egyik legjobban kutatott pénzhamisító hely a Szuhogy mellett található Csorbakő várában müködött. Itt a veretlen és ezüstözött rézlapkákon kívül különböző rézlemez-nyiradékokat, nyersanyagtömböket, kohósalakot, nagyobb mennyiségű olvasztótégelyt és természetesen hamis pénzeket is találtak (LESZIH 1941; SzÖRÉNYI 2003, 198-212).

A foúri pénzhamisítás időszaka az 1550-es években megszünt, azonban a pénzhamisítási esetek tovább folytatódtak, így I. Ferdinánd késői veretei, valamint I. Miksa (1564-1576) és I. Rudolf (1576-1608) király érméi között is szép számmal találunk hamis példányokat. A 16. század eleji pénzhamisítások több esetben a parasztsághoz köthetök (KAHLER 1975-1976, 54-55; GYÖNGYössy 2019, 102). Ez így volt a 16. század második felében és a 17. században is, amikor a hamisítást végzők újra az alsóbb néprétegek közül kerültek 
Varga Máté - K. Németh András •16-17. századi falusi pénzhamisitás régészeti nyomai Tolna megyében

ki, ezért ezt a korszakot a kovácshamisítványok időszakának is nevezik. Az eszközök és a technológia ekkor még kezdetleges, ennek megfelelően az éremképek gyengébb kivitelűek, az ezüsttartalom ingadozó, és jellemzően nem nagy mennyiségben készültek hamisítványok - mindez pontosan illik az alább bemutatandó emlékek többségére is. Ez a periódus az 1630-as évekig tartott (KÁPLÁR \& KAHLER 1976). Káplár és Kahler egy korábbi cikkben a kovácshamisítványok időszakát 1560-1660 közé tette (KÁPLÁR \& KAHLER 1973, 17).

\section{TOLNA MEGYEI LELŐHELYEK}

Tolna megyében az első, pénzhamisításhoz köthető leletek az 1980-as években kerültek elö Tevel és Bonyhádvarasd határában. A korábban ismert régészeti adatokat Gaál Attila terepbejárásai egészítették ki, aki egy tanulmányban közölte az előkerült leleteket (GAÁL 2006). Ezután a 2010-es években elsősorban az intenzív fémkeresős kutatásoknak, valamint a leletbeszolgáltatóknak köszönhetően újabb lelöhelyekkel gazdagodtunk (elökerülési sorrendben): Pincehely, Szakály (2 lelőhely), Gyulaj, Jágónak, Zomba, Kisdorog, Tolna. Így Tolna megyéből eddig összesen tíz lelöhelyröl ismertek a pénzhamisítás tárgyi emlékei (1. kép). Ez - a Kárpát-medencei adatokat is figyelembe véve - tekintélyes számnak mondható (VARGA \& NAGY 2017), hiszen azonos időszakhoz köthetö lelöhelyek ilyen fokú intenzitása csak a Felvidéken figyelhetö meg. Varga Máté és Nagy Zsolt 2015-ös gyüjtésében 26 lelőhely szerepelt, azonban az azóta eltelt időben ez a szám már 50 fölé emelkedett. Ezek azok a lelőhelyek, ahonnan tárgyi bizonyítékot ismerünk korabeli pénzhamisításra. További több mint 20 olyan helyről van tudomásunk, amelyet írott források említenek, de régészeti nyomuk eddig nem került elö, vagy nem tudunk róla.

Az egyes lelőhelyek kutatása és a leletanyag tisztítása, rendszerezése még folyamatban van, valamint az elökerült leletanyag nagysága miatt jelenleg csak a kutatásaink előzetes eredményeit adhatjuk közre. Általánosságban elmondható, hogy az illegális pénzhamisítás tevékenységére egyértelmüen utaló leletek a kerek - néha enyhén felhajló szélü-, veretlen rézlapkák és azok a rézlemezek - az ún. nyiradékok -, amelyekből a lapkákat kivágták (2. kép). A lapkákat olykor keskeny szalagokból ütötték ki (3. kép), ám ezek eddig csak Tolnáról kerültek elö. A lapkák lehetnek ezüstözöttek is, azonban ez nem figyelhetö meg minden esetben. Ebböl arra következtethetünk, hogy a lapkákat bizonyos esetekben az éremverés után vonták be ezüsttel. Lapka mindegyik lelőhelyen elökerült,

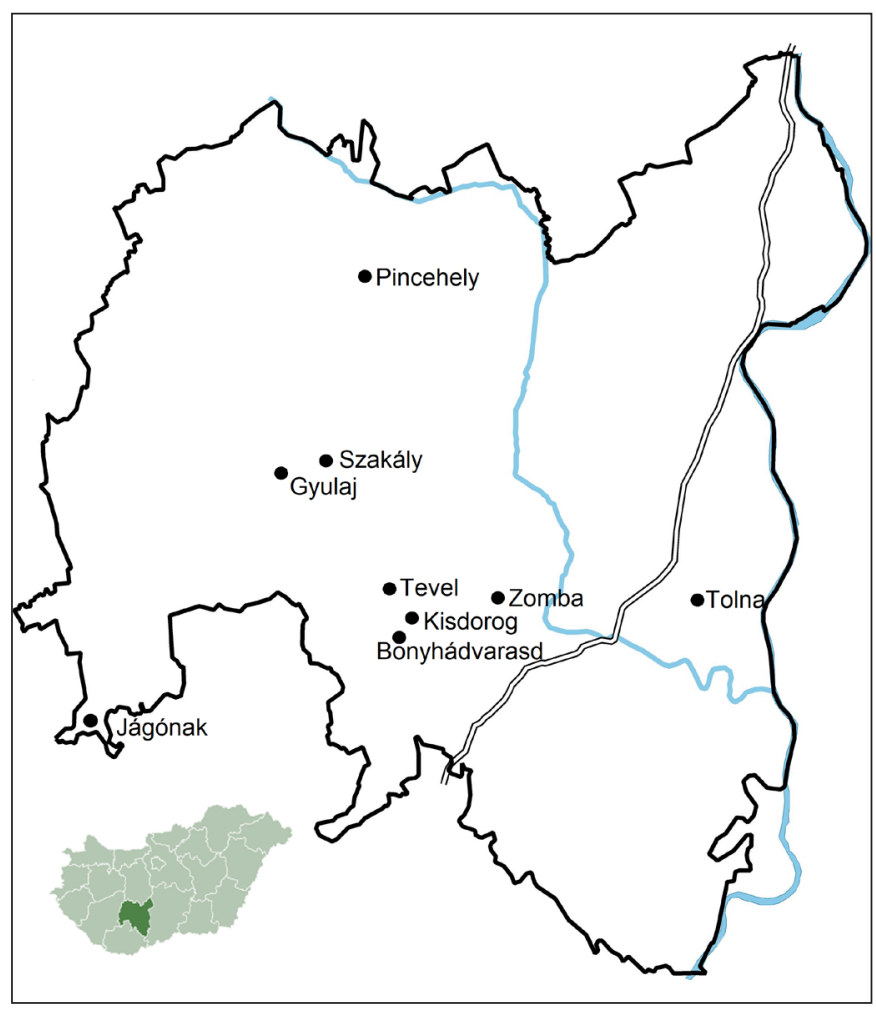

1. kép. Áttekintö térkép a tanulmányban emlitett lelőhelyekkel (alaptérkép: https://hu.wikipedia.org/wiki/Tolna megye; rajz: K. Németh András)

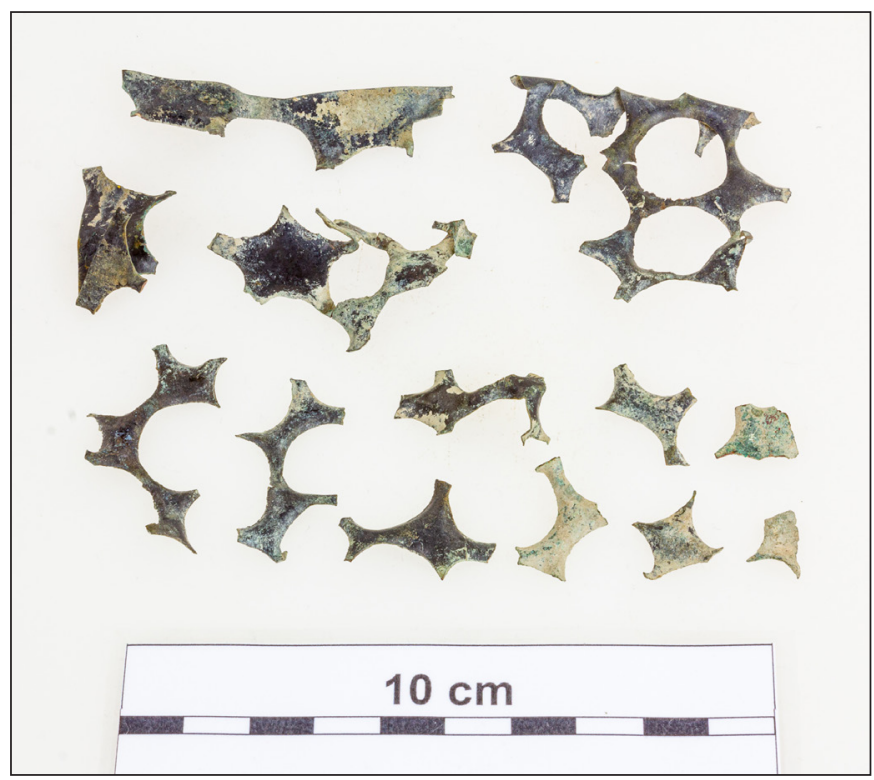

2. kép. Különbözö alakú nyiradékok Tolnáról (tisztitás elötti állapot) (fotó: Retkes Tamás) 
Varga Máté - K. Németh András • 16-17. századi falusi pénzhamisitás régészeti nyomai Tolna megyében

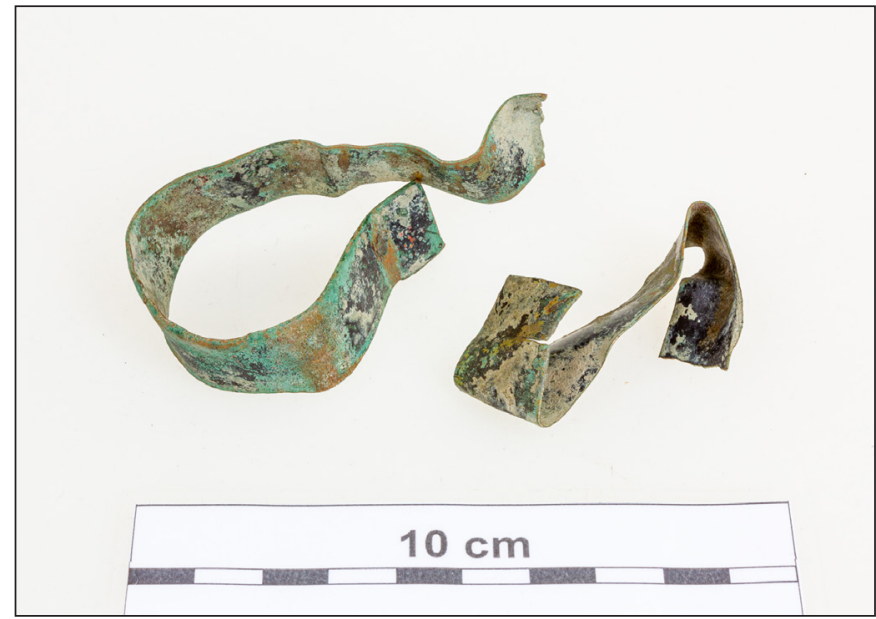

3. kép. Lapkák kiveréséhez elökészitett rézlemezcsikok

Tolnáról (tisztítás elötti állapot) (fotó: Retkes Tamás)

míg nyiradék egy lelőhely kivételével - ahol még nem volt lehetőségünk leletgyüjtésre, ezért csak a beszolgáltatott tárgyakra szorítkozhatunk - szintén az összes helyről ismert. A legtöbb lapka a pincehelyi (közel 100 darab; VARGA 2016) és a teveli (40 darab) lelőhelyről került elö, a többiről 1-20 közötti darabszám ismert. Nyiradékból a pincehelyi és a tolnai lelőhelyen került elő nagyobb mennyiség: Pincehelyen közel 500, Tolnán pedig több mint 170 darab (4. kép), míg a többi helyen 5-44 darabot találtunk. Egyes lelőhelyeken előkerültek további formájuk alapján olykor bizonyosan másodlagosan felhasznált - rézlemezek, amelyeket a nyersanyagok közé sorolhatunk, tehát további lapkákat terveztek belőlük kiütni (5. kép). Ezenkívül Tevelen és Bonyhádvarasdon kisebb ólom- és ónrögöket találtak (GAÁL 2006, 106, 125), amelyeket talán olvasztáshoz, ötvözéshez használhattak fel. Egyéb mühelyre utaló jelenség vagy lelet (kohó, salak, olvasztótégely, szerszámok) egyelöre egyik lelöhelyről sem ismert nagyobb számban, ám néhány lelet mégis megemlíthető. Szakályban bronzolvadékot, ólomlapkát és ötvöskalapácsot, Zombán pedig ólom- és bronzolvadék mellett kalapácsfejet és bronz poncolót (?) is gyüjtöttünk. Itt jegyezzük meg - és ez már részben a pénzhamisítás „elkövetőinek" kérdéséhez vezet át -, hogy Zombán elökerült egy olyan bronz préselőtő is, amely mintájának legközelebbi párhuzamai az Al-Duna vidékéről előkerült kincsleletekböl ismertek, és balkáni-törökös diadémnak vagy övnek határozták meg öket. A préselőtő jelzi, hogy a pénzhamisítással párhuzamosan más, hasonló tudást igénylő tevékenységek is folyhattak a lelöhelyeken.

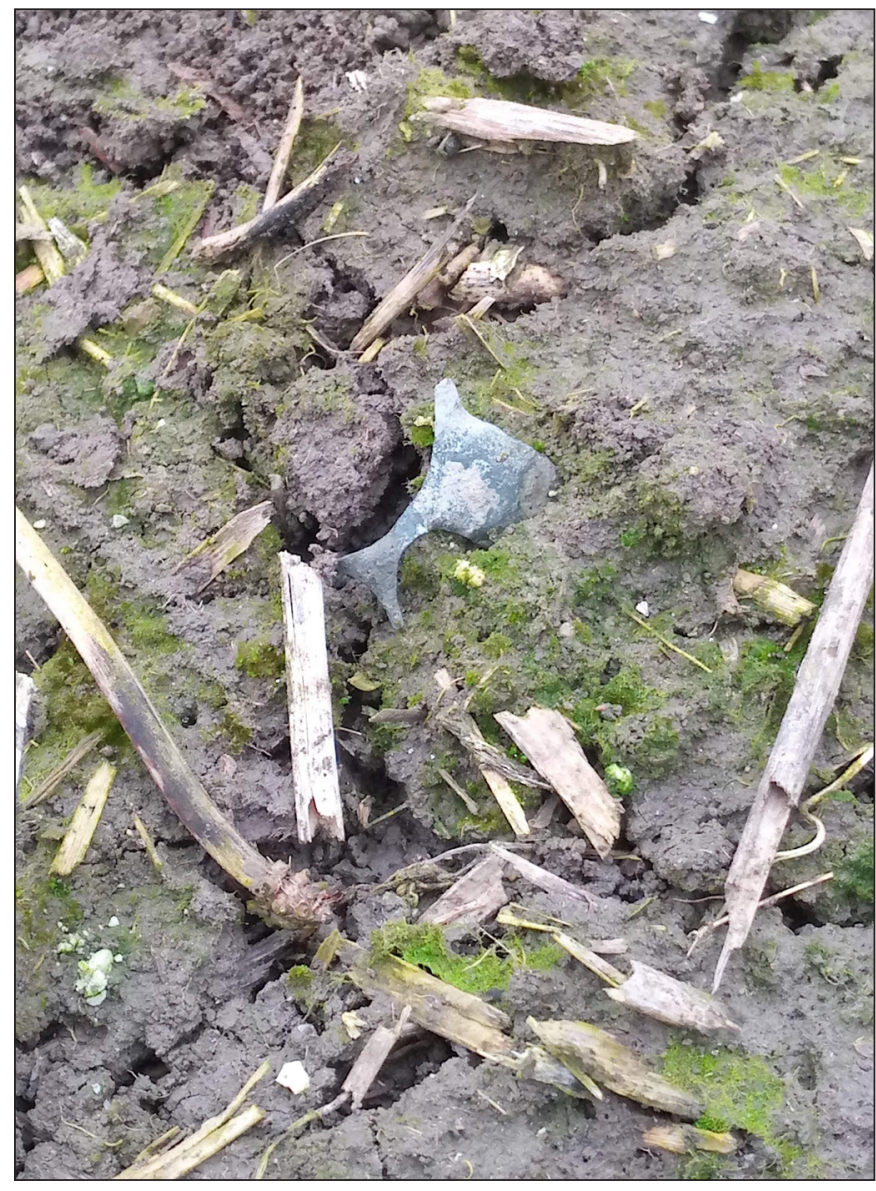

4. kép. Nyiradék a tolnai felszini leletgyüjtés során (fotó: K. Németh András)

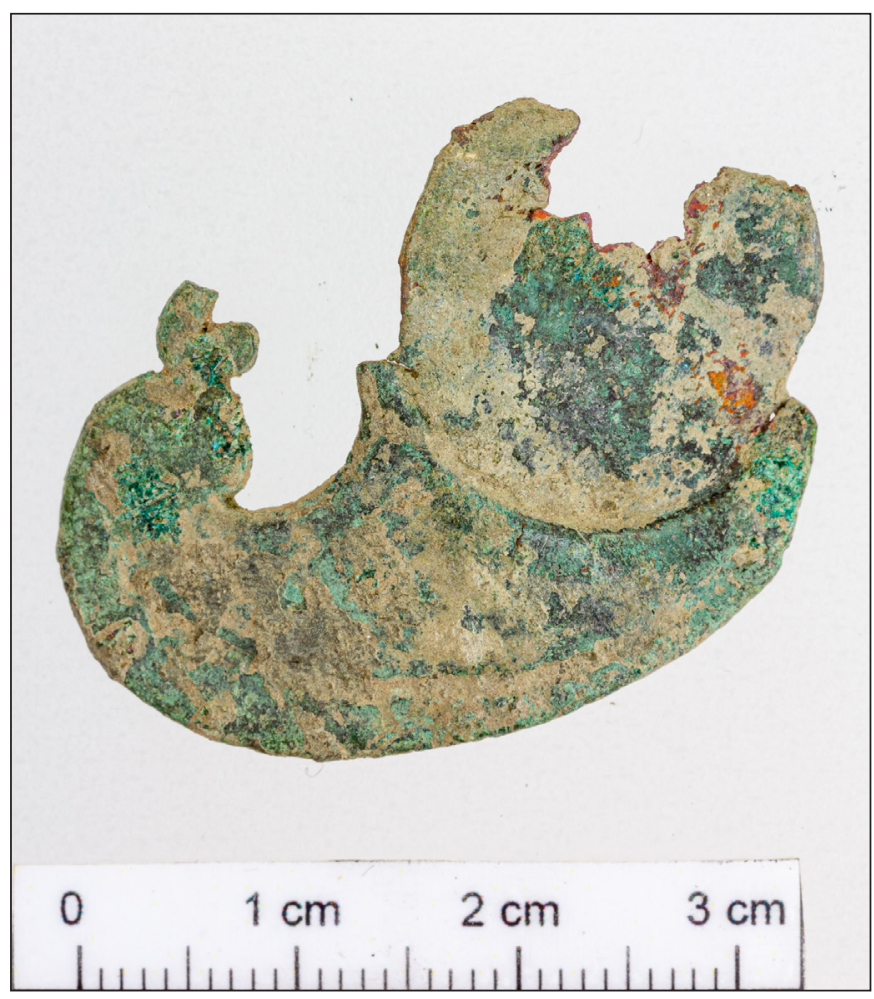

5. kép. A nyersanyagként használt lemezben maradt, rosszul kiütött lapka Kisdorogról (tisztítás elötti állapot) (fotó: Retkes Tamás) 
Varga Máté - K. Németh András •16-17. századi falusi pénzhamisitás régészeti nyomai Tolna megyében

\section{PÁRHUZAMOK}

A Tolna megyei lelöhelyekhez jellegében hasonlót nem sokat ismerünk a Kárpát-medencéböl. Legjobb párhuzamként a Kisboszniához (ma: Mala Bosna, Szerbia) tartozó Vámtelek-puszta határában talált leletek szolgálnak. Itt összesen négy különböző helyen találtak rézlapkákat (részben ezüstözöttek, esetleg ónozottak), nyiradékokat és hamis pénzeket. A négy lelőhely egy kilométeren belül található: három a Bács-ér (Krivaja) egyik, míg egy a másik oldalán. Az elsö leletben közel 120 darab - részben ezüstözött - rézlapka és közel 50 darab hamis érme, valamint nyiradékok voltak. A másodikban hamis denárok és nyiradékok láttak napvilágot. A harmadik leletben csak Rudolf király (1576-1608) hamis érméi találhatóak meg. A negyedikben ezüst érmék, hamis denárok, kerek, részben ezüstözött lapkák és nyiradékok is voltak. A lapkák többsége denár méretü, de van köztük garas és fél tallér nagyságú is. A pénzhamisítás az 1570-1580-as években történhetett (NAGY 2009-2010; NAGY 2011-2012).

Falusi lelőhelyről még további két adatot ismerünk, mindkettő a Tolnával szomszédos Bács-Kiskun megyében található. Kunpeszéren Pánya István közlése szerint egy darab rézlapka és két darab nyiradék került elö. Kunbaracson, a középkori Baracs falu területén öntőtégely-töredék, körülbelül tíz darab rézlapka és hamis érmék láttak napvilágot (BuZÁs, KöNIG \& PÁNYA 2019, 16-17). A szerzők feltételezése szerint az 1550-es években folyhatott itt pénzhamisító tevékenység, amely valószínü, hogy a foúri pénzhamisítások körébe sorolható.

A Tolna megyei lelőhelyek egyediségét mutatja az a tény is, hogy a környező dunántúli megyékben (Baranya, Fejér, Somogy) szintén folynak intenzív fémkeresős kutatással egybekötött terepbejárások, azonban eddig hasonló leletek egyik területen sem kerültek elő.

\section{A LELÖHELYEK FÖLDRAJZI HELYZETE ÉS KITERJEDÉSE}

A pénzhamisító mühelyek nem egységesen helyezkednek el Tolna megye területén. Az alföldi részen egyedül a tolnai található, a többi a megye északnyugati és középsö, dombsági területein fekszik. A KülsöSomogyban fekvő lelőhelyek közül a jágónaki és a pincehelyi a Kapos mellett helyezkedik el; a gyulaji és a két szakályi pedig a Kapos egy mellékágának a két oldalán, a víz közelében, enyhe domboldalakon terül el. A Tolnai-Hegyháton és a Völgységben találjuk a teveli és a zombai, illetve a bonyhádvarasdi és a kisdorogi lelőhelyet, a Völgységi-patakba északról folyó kisebb patakok mentén, a zombai kivételével szük völgyek oldalában. Egyes pénzhamisítók elhelyezkedésében megfigyelhető bizonyos koncentráció, ami alapján akár időbeli kapcsolat is feltételezhetö közöttük. Különösen gyanítható ez a gyulaji és a két szakályi mühely esetében, amelyek egy 500 méter sugarú körön belül helyezkednek el, és csak az egyik körül található faluhely, míg a másik kettő magányosan állt. A Völgységben és a Hegyháton is koncentrálódtak a lelőhelyek: a teveli, a zombai és a kisdorogi egymástól 10, 6, illetve 8 kilométerre fekszik, az általuk bezárt háromszög közepén pedig a bonyhádvarasdi helyezkedik el.

A tíz mühely közül csak egy található várban (Jágónak), a többi vagy falusias településeken létesült, vagy magányosan állt. A hamispénzverö mühelyeknek a nekik helyet adó települések jellege alapján két csoportja különíthető el: a középkori faluhelyeken, illetve a török hódítás után létrejött, középkori előzmények nélküli településeken berendezkedett mühelyek csoportja. A pincehelyi mühely Árpád-kori; a bonyhádvarasdi, a pincehelyi és a teveli pedig késő középkori előzményekre visszavezethető, a török korban is lakott faluhelyek területén helyezkedik el. A mühelyek felét olyan lelöhelyeken azonosítottuk, amelyek a keltezhető leletek - elsősorban érmék - alapján legkorábban a 16. század közepén jöttek létre (Gyulaj, Kisdorog, Szakály 1-2., Zomba). A felsorolt öt lelőhelyből három esetben (Gyulaj, Szakály 2., Kisdorog) maguk a pénzhamisító mühelyek jelentik a teljes lelöhelyet, azaz nincs körülöttük nagyobb településre utaló nyom. A jelenlegi tudásunk szerint tehát magányosan - valószínüleg a lakott helyektől szándékosan elkülönülve, „eldugva” - álltak. Hasonló, ,alkalmi” hamispénzverő helyet az ország más részéről írott forrásból is ismerünk: a már említett Miklós ötvösmester 1551-es pénzhamisítási perében parasztok arról számoltak be, hogy a csemernyei erdőben járva véletlenül hamispénzverö németekre bukkantak, akik „kemény fák törzsökén” verték a hamis pénzt (КомÁROMY 1893b, 757-758). 
Varga Máté - K. Németh András •16-17. századi falusi pénzhamisitás régészeti nyomai Tolna megyében

A mühelyek méretére felszíni leleteik alapján következtethetünk (nem számítva ide a nem feltétlenül helyben készült hamis pénzeket). A lapkák és a nyiradékok által kijelölt területek nagysága két véglet között ingadozik: Zombán kb. 160×90, Tolnán pedig 100×60 méter; ellenben Gyulajon és Tevelen csak 40×20-30, Bonyhádvarasdon viszont mindössze kb. 20×10 méter. Ezek alapján legalább egy nagyobb méretü, hosszabb ideig működő, valamint egy kisebb - nagyjából egy házhely, telek méretü (?) -, valószínűleg rövid ideig vagy csak alkalmilag termelő műhelytípust különíthetünk el. Egyedül Zombán figyeltünk meg a hamispénzverés tárgyi emlékei által kijelölt területen belül egy kisebb méretü tégla- és habarcstörmelékes foltot, amely akár maga a mühely épületét is jelölheti.

\section{A TOLNA MEGYEI LELŐHELYEK KELTEZÉSE ÉS A HAMISÍTÓK LEHETSÉGES KÖRE}

A pénzhamisításhoz köthető lelőhelyek anyagának keltezése nem könnyü feladat, hiszen önmagukban a rézlapkák és a nyiradékok nem bírnak keltező értékkel. A keltezést nehezíti az is, hogy minden esetben csak felszíni leletgyüjtés történt. Segítségünkre lehetnek a lapkák átmérő- és súlyadatai, hiszen azok összevethetők a korabeli, a hamisítás mintaképéül vett érmékkel, illetve a lelöhelyeken talált hamis pénzekkel. A Tolna megyei lelőhelyeken megfigyelt lapkák legnagyobb része denár méretü lapka (6. kép), mindössze néhány esetben figyelhettünk meg ennél nagyobb méretet.

A több száz éven keresztül használt lelöhelyek esetében számos olyan érme és tárgy is előkerült, amely nem könnyíti meg a pénzhamisítás időbeli behatárolását. Hiszen ha elökerültek a 16. és 17. századból is hamis érmék, akkor melyikhez köthetjük a hamisítást? Egyes lelőhelyeknél azonban csakis egy adott, rövidebb periódusból kerültek elö, vagy egy rövidebb időszakra koncentrálódnak a datálást segítő érmék és egyéb leletek. Például a pincehelyi lelőhelyen a 12-13. századtól kezdve kerültek elő érmék egészen a 17. századig. Hamis pénzek találhatóak I. Ferdinánd, I. Miksa és I. Rudolf, de

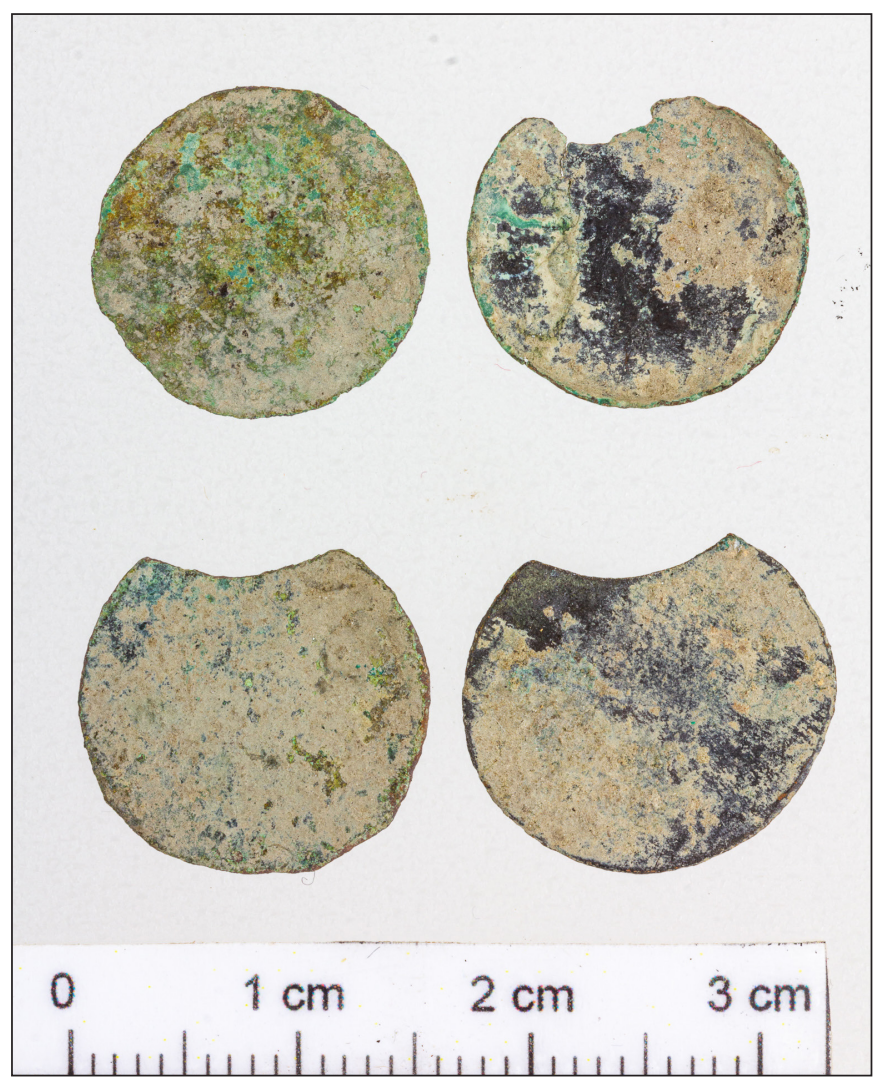

6. kép. Denár méretü lapkák Tolnáról (tisztitás elötti állapot) (fotó: Retkes Tamás) II. Ferdinánd (1619-1637) veretei között is, így elméletben mindegyik uralkodó korszakához köthetnénk az itteni pénzhamisítást. Az előkerült rézlapkák átmérő- és súlyadatai azonban sokkal inkább II. Ferdinánd korszaka felé mutatnak.

Ezek alapján a kisdorogi, a teveli és a bonyhádvarasdi lelőhelyeket a 17. század elejére; a pincehelyi lelőhelyet a 17. század első felére; míg az egyik szakályi és a gyulaji lelőhelyet a 16. század végére, a 17. század elejére keltezhetjük (7-8. kép). A Jágónakon, Zombán, Tolnán, illetve a másik szakályi lelőhelyen talált viszonylag kevés számú lelet keltezése egyelőre bizonytalan, bár a szakályi esetében szintén valószínü, hogy a 16. század végén, a 17. század elején használhatták, ugyanis a két szakályi és a gyulaji lelőhely nagyon közel található egymáshoz. Az előkerült lapkák és a nyiradékok formai jegyei alapján a jágónaki, a zombai és a tolnai lelőhelyen is a 16-17. században végezhettek pénzhamisítást.

Itt csak röviden utalunk egyes - a keltezés kapcsán már említett -, elsősorban 17. századi pénzhamisító mühelyek (mindenekelőtt Pincehely és Zomba, továbbá Bonyhádvarasd, Tevel, valamint a gyulaji-szakályi mühelykomplexum) lehetséges használóira, létrehozóira. Nem hagyható figyelmen kívül az a tény, hogy Tolna megye lakosságának jelentős részét a tizenöt éves háború (1591-1606) utáni évtizedekben a kortársak 
Varga Máté - K. Németh András •16-17. századi falusi pénzhamisitás régészeti nyomai Tolna megyében

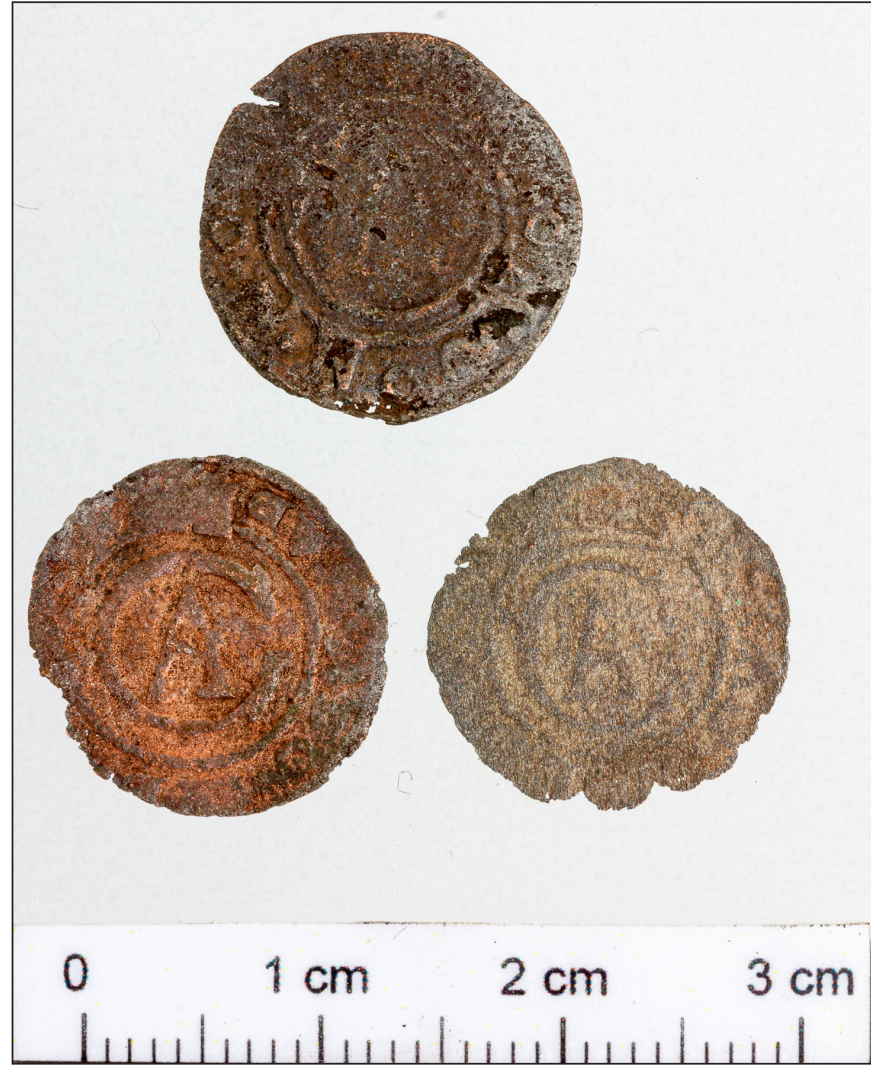

7. kép. II. Gusztáv Adolf (1611-1632) svéd király nevére vert hamis érmék Kisdorogról (tisztitás elötti állapot) (fotó: Retkes Tamás)

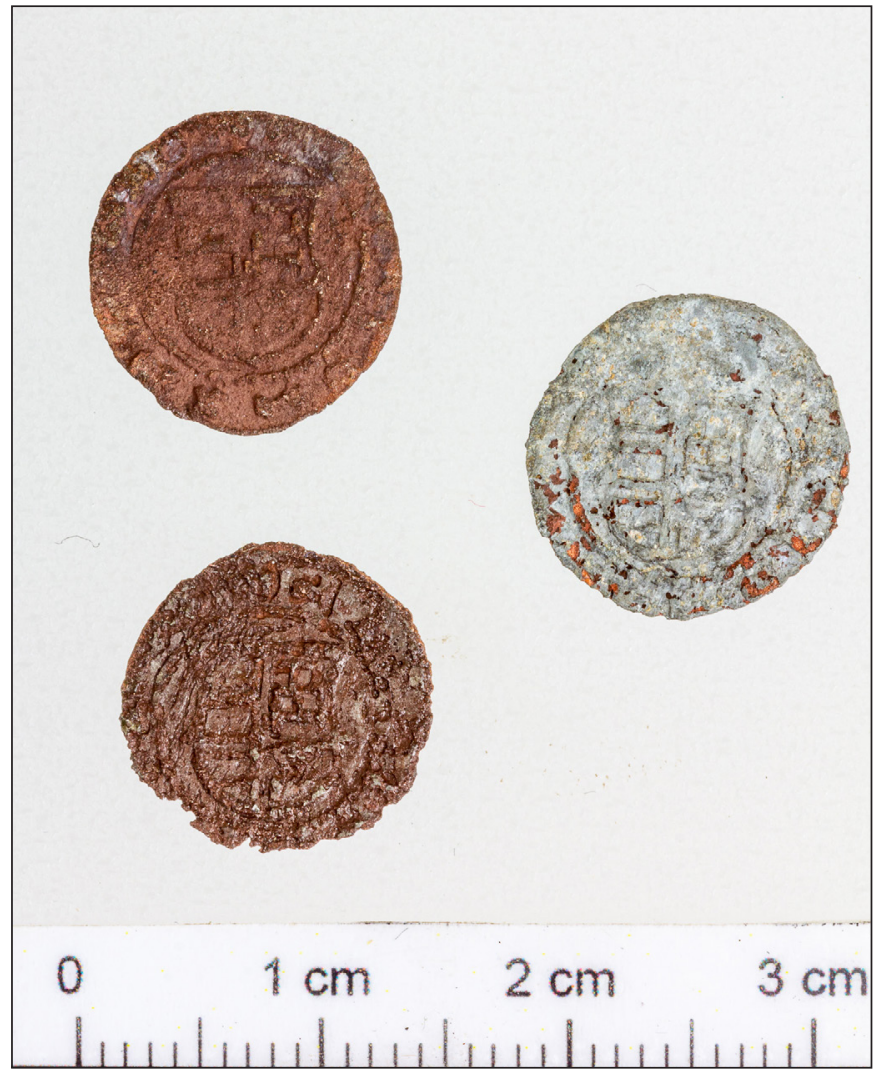

8. kép. 17. század eleji hamis denárok Gyulajról (restaurált állapot) (fotó: Retkes Tamás)

által általában rácnak nevezett balkáni - többnyire délszláv - eredetű népelemek tették ki, akik gyakran nem az elpusztult középkori magyar falvak helyén rendezkedtek be, hanem azok határában új, önálló telepeket hoztak létre. Itt nem áll módunkban kifejteni ennek egyre gyarapodó régészeti nyomait és bizonyítékait, de egyes középkori előzmények nélküli, török kori telepeken azonosított pénzhamisítási nyomok esetében erős a gyanú, hogy ezek az említett népességhez köthetők, amit a zombai mühely kapcsán említett préselötő is jelez.

\section{KÖSZÖNETNYILVÁNÍTÁS}

A tolnai lelőhelyet K. Tóth Gábor régész, a kisdorogit Fazekas András múzeumbarát fémkeresős azonosította, a szakályi és gyulaji lelőhelyekről egy anonimitást kérő gyűjtőtől szereztünk tudomást. A fentieken kívül köszönjük Czövek Attila régész; Bulla László, Jókai Attila, Kántor Miklós, Korossy Attila, Mészáros Péter, Sándor Lajos, Vincze Péter, Wagner Krisztián múzeumbarát fémkeresős; Künsztler Gábor Tamás, Tövisháti András és Ács Vince restaurátor; valamint Retkes Tamás fotós munkáját, segítségét.

\section{AJÁNLOTT IRODALOM}

Bohdaneczky, I. (1935-1936). A pénzhamisítás Magyarországon a középkorban. Numizmatikai Közlöny 34-35, 48-58.

Huszár, L. (1969). Magyar várak, mint pénzhamisító műhelyek a XVI. században. Müemlékvédelem 13 (2), $80-87$.

Komáromy, A. (1893a). Egy hamis pénzverő a XVI. században. Századok 27 (8), 647-667. 
Varga Máté - K. Németh András •16-17. századi falusi pénzhamisitás régészeti nyomai Tolna megyében

Komáromy, A. (1893b). Egy hamis pénzverő a XVI. században. Második és befejező közlemény. Századok 27 (9), 748-759.

Varga, M. \& Nagy, Zs. D. (2017). Coin counterfeiter workshops in Hungary during Medieval and Early Modern Ages. In B. Zajac et al. (eds.), Pecunia Omnes Vincit. The coins as an evidence of propaganda, reorganization and forgery. Conference proceedings of the 2 nd international numismatic conference, Krakow, 29-30 May 2015 (pp. 123-143). Kraków: Institute of Archaeology, Jagiellonian University.

BiBLIOGRÁFIA

Buzás, G., Kőnig, F. \& Pánya, I. (2019). Középkori templomok nyomában Bács-Kiskun megyében I. Várak, kastélyok, templomok 15 (2), 14-17.

Gaál, A. (2006). Falusi pénzhamisító mühelyek emlékanyaga a Tolna megyei Tevel és Bonyhádvarasd határából (Gedenkmaterial der ländlichen Geldfälscherwerkstätte aus der Mark der Gemeinden Tevel und Bonyhádvarasd im Komitat Tolnau). A Wosinsky Mór Múzeum Évkönyve 28, 105-132.

Gyöngyössy, M. (2019). Pankart és csopce. Pénzverés és pénzforgalom Nyugat-Magyarországon (13871608). Mosonmagyaróvár: Hansági Múzeum.

Kahler, F. (1975-1976). A XVI. századi pénzhamisítás kérdéséhez (Zur Frage der Falschmünzerei im XVI. Jahrhundert). Numizmatikai Közlöny 74-75, 53-56.

Kahler, F. (1977-1978). A magyarországi középkori pénzhamisítás (I. rész) (Mittelalterliche Falschgeldprägung in Ungarn). Numizmatikai Közlöny 76-77, 57-65.

Kahler, F. (1981-1982). Középkori pénzhamisításunk kérdéséhez (III. befejező rész) (Die mittelalterliche Geldfälschung in Ungarn (abschließender Teil). Numizmatikai Közlöny 80-81, 79-83.

Káplár, L. \& Kahler, F. (1973). Adatok a XVI. századi pénzhamisítás kérdéséhez. Az Érem 29 (1), 17-21.

Káplár, L. \& Kahler, F. (1976). Adatok a magyarországi pénzhamisítás kérdéseihez; a pénzhamisítás technikájának alakulása az újkorban (Angaben zur Frage der Falschmünzerei in Ungarn. Die Gestaltung der Technik der Falschmünzerei in der Neuzeit). Déri Múzeum Évkönyve 1976 (1977), 137-149.

Komáromy, A. (1893a). Egy hamis pénzverő a XVI. században. Századok 27 (8), 647-667.

Komáromy, A. (1893b). Egy hamis pénzverő a XVI. században. Második és befejező közlemény. Századok 27 (9), 748-759.

Leszih, A. (1941). A szuhogyi csorbakői vár XVI. századbeli pénzhamisító műhelye. Numizmatikai Közlöny $40,49-54$.

Nagy, J. (2009-2010). Két XVI. századi hamis éremlelet Vámtelekről (Zwei Falschmünzfunde aus dem 16. Jahrhundert in Vámtelek). Numizmatikai Közlöny 108-109, 215-222.

Nagy, J. (2011-2012). Újabb két XVI. századi hamis éremlelet Vámtelekről (Zwei neue Falschmünzfunde aus dem 16. Jahrhundert in Vámtelek). Numizmatikai Közlöny 110-111, 139-144. 
Varga Máté - K. Németh András •16-17. századi falusi pénzhamisitás régészeti nyomai Tolna megyében

Szörényi, G. A. (2003). A csorbakői vár története 1648-ig (The history of the castle of Csorbakő until 1648). A Herman Ottó Múzeum Évkönyve 42, 165-226.

Varga, M. (2016). 17. századi pénzhamisító mühely leletei Pincehely határából (Fundobjekte einer Geldfälscherwerkstatt aus dem 17. Jahrhundert am Flur von Pincehely). A Wosinsky Mór Múzeum Évkönyve 38, 329-348.

Varga, M. \& Nagy, Zs. D. (2017). Coin counterfeiter workshops in Hungary during Medieval and Early Modern Ages. In B. Zajac et al. (eds.), Pecunia Omnes Vincit. The coins as an evidence of propaganda, reorganization and forgery. Conference proceedings of the 2 nd international numismatic conference, Krakow, 29-30 May 2015 (pp. 123-143). Kraków: Institute of Archaeology, Jagiellonian University. 